\title{
A AUTOBIOGRAFIA COMO PREPARAÇÃO DA CRÍTICA LITERÁRIA E DA IMAGEM DO AUTOR: MANUEL BANDEIRA E OSWALD DE ANDRADE
}

\section{THE AUTOBIOGRAPHY AS A PREPARATION OF THE LITERARY CRITIC AND OF THE AUTHOR'S IMAGE: MANUEL BANDEIRA AND OSWALD DE ANDRADE}

Daniel da Silva Moreira

Universidade Federal de Juiz de Fora, UFJF, Juiz de Fora, MG, Brasil

Resumo: Este texto tem por objetivo desenvolver uma reflexão sobre a autobiografia como espaço de criação e de legitimação de uma imagem desejada de autor e, ao mesmo tempo, de articulaçâo prévia da leitura crítica da obra literária como um todo. Para evidenciar esses processos de legitimação de imagem e de interpretação da obra literária, recorre-se às autobiografias de Manuel Bandeira, o Itinerário de Pasárgada, e de Oswald de Andrade, Um homem sem profissão.

Palavras-chave: Literatura brasileira; autobiografia; Manuel Bandeira; Oswald de Andrade.

Abstract: This text aims to develop a reflection on the autobiography as a space of creation and legitimation of a desired image of author and, at the same time, of previous articulation of the critical interpretation of their literary works. To highlight these processes of image and literary criticism legitimation I'll work with two Brazilian autobiographies, Itinerário de Pasárgada, by Manuel Bandeira, and Um homem sem profissão, by Oswald de Andrade.

Keywords: Brazilian literature; autobiography; Manuel Bandeira; Oswald de Andrade.

Há duas autobiografias brasileiras, ambas publicadas originalmente em 1954, que se prestam - a meu ver, melhor que quaisquer outras - a uma interessante reflexáo sobre a construçáo de uma imagem de autor, bem como sobre o emprego das escritas de si como meio de legitimar uma determinada leitura crítica da própria obra literária.

A primeira delas é o Itinerário de Pasárgada, de Manuel Bandeira, texto que estava, inicialmente, destinado a uma revista que Fernando Sabino e Paulo Mendes Campos pretendiam publicar, a Revista Literária, mas que acabou gorando. De todo modo, o texto ganhou a forma de livro pela editora do Jornal de Letras (Cf. SABINO, 1996, p. 265). O ponto de partida para a 
autobiografia do poeta são suas primeiras recordaçôes de infância, uma vez que, segundo ele, tais lembranças encerrariam um conteúdo inesgotável de emoção que, como diz Bandeira (1958, p. 110), "A certa altura da vida vim a identificar essa emoçáo com outra - a de natureza artística”. A partir de tais recordaçóes se desenrola toda a narrativa de uma vida em que Bandeira busca reconstituir a origem de sua poética, trazendo cada lembrança, cada episódio, para dar conta de uma grande questâo: como se configurou o itinerário que levou o menino que fazia versos "com o mesmo espírito desportivo com que" se "equilibrava sobre um barril" (BANDEIRA, 1958, p. 20) a ser o poeta de Pasárgada, que, aos 68 anos de idade, afirma "Saibam todos que fora da poesia me sinto sempre um intruso" (BANDEIRA, 1958, p. 90). A autobiografia de Bandeira é, de fato, um itinerário intelectual, ou seja, uma narrativa que busca reconstituir o caminho de sua formação de um modo bastante tradicional. Por esse caminho, que segue quase que exclusivamente a vida pública de Bandeira, seu vínculo com o mundo das letras e das artes, passam, ao longo de 21 pequenos capítulos, assuntos como suas primeiras leituras e seus primeiros anos de estudo, as influências recebidas de outras artes, a publicação de cada um de seus livros, a composição de seus principais poemas, sua atuação como professor, seu ingresso na Academia Brasileira de Letras e seus muitos contatos e amizades intelectuais. A vida íntima é cuidadosamente resguardada, percebendose, assim, um movimento autobiográfico que se distingue do confessional e que se aproxima em muito do modelo de autobiografia executado por José de Alencar em Como e porque sou romancista, em que os "fatos" da vida interior, e mesmo os sentimentos, apenas são evocados com o intuito de explicar a obra. Além disso, a postura que Bandeira assume, diante do fazer autobiográfico, é bastante reveladora de uma tentativa de mostrar-se distanciado do desejo e da iniciativa da escrita daquele relato, o que pode ser visto até mesmo na dedicatória do livro: "A Fernando Sabino, / Paulo Mendes Campos / \& João Condé, / que me fizeram escrever este livro, dedico-o" (BANDEIRA, 1958, p. 07, grifo meu). O poeta vai encaminhar até o fim sua narrativa empregando um tom parecido, isto é, aquele de um escritor que foi quase que forçado por terceiros a escrever suas memórias, capaz de afirmar, mais tarde, algo como: "Confesso que já me vou sentindo bastante arrependido de ter começado estas memórias” (BANDEIRA, 1958, p. 21), ou, ainda, já próximo ao final do texto: "estas memórias já me vão cansando" (BANDEIRA, 1958, p. 104). Minha leitura dessa negaçáo que Bandeira faz da escrita autobiográfica, que, no entanto, está praticando, é de que a rejeiçáo constante se constitui como um artifício que permite ao 
seu autor se entregar à autobiografia e articulá-la segundo seus interesses na representaçáo de si, sem que com isso seu depoimento pareça intencional ou premeditado, sem que o leitor possa supor que no que vai escrito haja o desejo de moldar a realidade, de moldar sua vida em consonância com uma imagem pública que ambicionava que permanecesse. Assim, o ato de negar constantemente o que se está escrevendo legitima o testemunho ou a automodelagem, pois sinaliza para o leitor que aquilo que lhe é apresentado não foi escrito para atender a uma necessidade pessoal e narcísica, mas sim a um pedido externo, ao qual o autor se representa como absolutamente alheio. E, de fato, é possível constatar, como mostrarei a seguir, que o poeta realmente busca fixar, através do Itinerário, uma imagem de si que pende em direçáo à confirmação de toda a mitologia que Bandeira criou, ao longo do tempo, em sua obra poética.

A outra autobiografia trata-se de Um homem sem profissáo; memórias e confissóes; sob as ordens de mamáe, que seria apenas o primeiro volume do projeto autobiográfico de Oswald de Andrade ${ }^{1}$, mas terminou sendo o único que foi de fato escrito e publicado alguns meses antes de sua morte. Em sua autobiografia, Oswald parece cumprir o protocolo confessional anunciado no subtítulo - memórias e confissóes -, optando por compor uma narrativa em que há a predominância do desnudar-se sem pudor, relatando mesmo os pormenores mais íntimos de sua vida, dando detalhes que, para muitos, soariam como bastante embaraçosos. Seu texto parte da recordação da infância e dos tempos escolares - com destaque à figura da mãe -, passa pela descoberta da sexualidade, pelo início de sua vida intelectual, pela descoberta da Europa, para chegar ao clima de efervescência cultural que antecedeu a Semana de Arte Moderna de 1922. Todavia, ainda que escreva um texto em que se entrega sem tantas reservas, Oswald também parece lançar mão de um expediente que em muito lembra o de Bandeira. Logo nas primeiras páginas de suas memórias, Oswald registra a gênese de Um homem sem profissão com a seguinte declaração: "Antonio Candido diz que uma literatura só adquire maioridade com memórias, cartas e documentos pessoais e me fez jurar que tentarei escrever já este diário confessional" (ANDRADE, 2002, p. 36). Ainda que Oswald assuma brevemente uma atitude de negação da intencionalidade de sua narrativa, minha leitura de Um homem sem profissáo parte da ideia de que a atitude predominante do autor em relação à escrita de sua autobiografia - de entrega e valorização do que possa haver de mais íntimo - não é um gesto

1 Os outros três volumes teriam os títulos: O Saláo e a Selva, Solo das Catacumbas e Para lá do trapézio sem rede. 
gratuito, é antes uma estratégia de afirmação de uma persona literária, que vai confirmar e legitimar a figura do intelectual transgressor e vanguardista pretendida por seu autor. À dessacralização da poesia empreendida por sua obra, por exemplo, poderia corresponder também, paralelamente, uma dessacralização da vida, a retirada da figura do intelectual de um pedestal, mostrando-o como uma criatura comum, feita de carne e de desejo. E, assim sendo, a autobiografia de Oswald constituir-se-ia como um ato crítico continuador da proposta estética e política de sua obra.

Ao comparar as atitudes de Bandeira e Oswald a outros exemplos de autobiografias intelectuais, pode-se constatar que a negaçáo da intencionalidade do relato é uma constante, não é raro que o autobiógrafo principie seu relato com uma série de escusas e justificativas por ter começado a escrever sobre sua vida. Diferentemente de outros tipos de testemunho, a autobiografia intelectual, por via de regra, parte de um indivíduo que já tem uma imagem pregressa - definida por sua obra ou por sua atuação pública - com a qual deve lidar, seja para preservá-la, seja para modificá-la. $\mathrm{O}$ intelectual, portanto, não parte do zero, não pode se escrever e redefinir por inteiro. E, para ele, mesmo o ato de ceder à autobiografia precisa ser relativizado - e nesse ponto entrariam as profusas negações - para não ser confundido com vaidade desnecessária, com exercício narcisístico ou egocentrismo exacerbado. Tais acusaçôes impóem-se ao autobiógrafo como uma verdadeira patrulha moral, em que qualquer traço de narcisismo, que possa transparecer na escrita, torna-se imensamente indesejável. Além disso, o intelectual já figura no senso comum como aquele que é mais capaz de modular e direcionar seu discurso para atingir seus objetivos, tudo que escrevesse seria, portanto, tomado como excessivamente intencional e, nessas circunstâncias, a negação assume o papel de fazer com que o discurso pareça mais imparcial, mais neutro. A meu ver, o intelectual divide-se entre dois extremos: de um lado, a pressáo social - exatamente pelo reconhecimento dessas figuras como intelectuais - para que registre o testemunho de sua vida, especialmente porque, como afirma Philippe Artières (1998, p. 14), "é um dever produzir lembranças, não fazê-lo é reconhecer um fracasso, é confessar a existência de segredos"; e, de outro lado, a negaçáo do narrar a própria vida, que, todavia, se se interpreta como propóe Wander Melo Miranda (1992, p. 25, grifo do autor), a autobiografia "não como um simples enunciado, mas como um ato de discurso ou, mais que isso, um ato de discurso literariamente intencionado", se torna difícil aceitar ipsis litteris. Nesse caso, é mais aceitável que se identifique a negação como um mecanismo que dê suporte à própria prática de escrever sobre si numa 
condição bastante específica: a do intelectual, já reconhecido, que se vê na situação de ter de passar sua vida a limpo.

Nesse contexto, é interessante observar a forma como as autobiografias podem constituir-se como um exercício de crítica literária da própria obra e como, pelo tipo de leitura que se costuma fazer dos textos autobiográficos, meios de acesso a uma verdade revelada sobre o autor, ela acaba sendo um fator de forte influência nas abordagens posteriores da obra do autobiógrafo. Nas mãos de autores como Bandeira e Oswald, ao que tudo indica, conscientes dessa força crítica do escrito autobiográfico, é grande o rendimento de suas escritas no sentido de realizar tanto uma preparaçáo crítica da recepção e estudo de suas obras quanto a afirmaçáo de uma persona literária para a posteridade. Seria algo muito semelhante ao que Eneida Maria de Souza, em Crítica Cult, descreve nos seguintes termos:

A figura do escritor substitui a do autor, a partir do momento que ele assume uma identidade mitológica, fantasmática e midiática. Esta personagem, construída tanto pelo escritor quanto pelos leitores, desempenha vários papéis de acordo com as imagens, as poses e as representaçóes coletivas que cada época propốe aos seus intérpretes da literatura. Cada escritor, portanto, constrói sua biografia com base na rede imaginária tecida em favor de um lugar a ser ocupado na posteridade: ou o do ausente ou do morto, pois também a morte cultiva seus teatros, como o palhaço e o dandy. (SOUZA, 2002, p. 110)

Assim, cada escritor vai compor sua "rede imaginária", entre o que se pode incluir seguramente sua produção autobiográfica, com vistas ao lugar que deseja ocupar no futuro, pensando tanto em como deseja que sua obra seja lida, quanto em como seja ele mesmo lido como intelectual, como personalidade. A meu ver, aqui há dois processos indissociáveis que se confundem numa verdadeira via de mão-dupla.

Ao realizar um primeiro levantamento das principais questóes tratadas pelo Itinerário de Pasárgada, é possível constatar que, quase em sua totalidade, se referem a pontos de possível polêmica ou obscuridade na obra e na vida de Bandeira, e, assim, pode-se compreender com bastante clareza o interesse que a autobiografia guarda para o poeta no momento de sua escrita. Manuel Bandeira, a despeito de seu pretenso afastamento do Itinerário, tira o melhor proveito possível de seu testemunho, é como se o poeta o tomasse como instrumento de combate, como uma oportunidade preciosa de ele mesmo delinear a imagem de si e as principais linhas críticas de interpretação de sua obra que passariam para a posteridade. Cito, a título 
de exemplo, o que o poeta escreve sobre a Homenagem a Manuel Bandeira que se organizou por ocasiáo de seu aniversário de cinquenta anos, um volume contendo mais de trinta peças - entre estudos críticos, depoimentos e poemas - relacionadas a Bandeira e sua obra; o poeta diz: "Quem quer que queira estudar a minha poesia e a da minha geraçáo náo pode dispensar a leitura desse livro" (BANDEIRA, 1958, p. 100). Igualmente significativo é o resgate que o poeta faz, ao comentar cada um de seus livros de poemas, da crítica recebida na época da publicação dos volumes. Resgatar a recepção de seus livros é algo bastante expressivo, pois, além de retirar a crítica literária da efemeridade do jornal, projetando-a na perenidade do livro, sugere uma releitura da obra - especialmente da produção inicial -, suscitando sua reavaliação e, por conseguinte, sua revalidação. $O$ interesse está em ver que é o próprio poeta quem seleciona exatamente quais críticas e que fragmentos delas transpor para o livro, o que pressupóe uma noção de crítica e análise literária em que a intenção é que conta e que o próprio poeta seria o mais abalizado para explicar e interpretar sua obra, algo no mínimo discutível. Se acertadas ou náo, se boas ou más, profundas ou superficiais, o leitor, e mesmo o pesquisador, só tem acesso a essa crítica hoje (e mesmo na década de 1950, quando a autobiografia foi escrita) através do que Bandeira selecionou, do panorama por ele traçado, visto que, no mais das vezes, é muito mais difícil pesquisar na fonte os jornais e revistas literárias aos quais o poeta se refere do que se fiar em sua escolha. Bandeira privilegia uma determinada interpretaçáo de sua obra, seleciona-a como adequada e projeta-a para leitores futuros. Há ainda, no Itinerário, uma espécie de defesa $^{2}$ do Mafuá do Malungo, livro de poemas de circunstância e sobre o qual desde sua publicaçáa pesou a acusação de representar a decadência de sua poesia - que leva Bandeira a explicitar as particularidades sobre edição do livro, bem como a fazer uma defesa da poesia de cortesia. Como esses, há um grande número de outros temas de interesse - e de polêmica - que podem

2 Na autobiografia, a confissão cumpre com frequência a função de autodefesa. Como mostrou Gisèle Mathieu-Castellani, certas escritas de si - seus exempos são Jean-Jacques Rosseau, André Gide Claude Roy, Jean Genet, Louis Althusser e Ingmar Bergman - encenam um tribunal imaginário diante do qual vem solenemente depor um culpado, constituindo "um interminável processo, onde juízes, um (pequeno) juiz, ou o (grande) Juiz, vão ouvir a declaração de um acusado, acompanhado por suas testemunhas, escoltado por seus advogados" (MATHIEU-CASTELLANI, 1996, p. 14, tradução nossa). Embora nem todos os autobiografos assumam esse discurso judiciário, a autocrítica e a contracrítica são amiúde parte integrante de toda autobiografia intelectual, quando não constituem seu próprio móbil. Através dela, reconhecem-se os enganos esboça-se uma defesa contra os juízos adversos ao pensamento ou à obra do autor. A autobiografia funciona, desse modo, como um discurso de persuasão dirigido ao leitor. 
ser levantados a partir do Itinerário, como a entrada de Bandeira para a Academia Brasileira de Letras, sua participação na Semana de Arte Moderna de 1922, as raízes populares e orais de sua poesia, a relação entre a música e seus versos, a formação da mitologia de sua obra, sua formaçáo como poeta e intelectual e outras questóes que tornam patentes o ininterrupto diálogo que sua prosa traça com o restante de sua obra e também o processo de construção de uma imagem de intelectual. Os eventos e as histórias elencados pelo poeta seguem, quase sempre, um esquema narrativo muito racional, ao tentar explicar os acontecimentos, com um expresso apego pela ordem e uma busca constante de uma harmonia ao relatar a própria vida. Nunca se pode observar uma "sobra" de elementos no narrado, tudo parece colocado num lugar cuidadosamente pensado e os fatos são reduzidos ao mínimo necessário, não há a entrega de detalhes íntimos, o que é possível encontrar na autobiografia de Oswald, por exemplo.

Um dos pontos centrais do direcionamento crítico que o poeta faz de sua obra, a partir do Itinerário de Pasárgada, e no qual me detenho mais demoradamente nesse momento, é a definiçáo de si mesmo como um poeta menor. Bandeira estabelece novos parâmetros de leitura para a sua poesia, ao escolher exatamente qual significado deseja atribuir a poesia menor - poesia do cotidiano e nấo poesia inferior - $\mathrm{e}$, ainda que o poeta pareça oscilar entre a própria depreciação e exaltação, o resultado de tal procedimento será, como mostrarei adiante, não só um Bandeira poeta menor, segundo a definição que mais lhe interessa, mas também um poeta em situação diametralmente oposta à do poeta inferior; o que sai do Itinerário é um Bandeira cuja poesia é fruto de um longo processo de refinamento técnico. $\mathrm{O}$ termo poeta menor remonta à tradição literária da Antiguidade clássica, sendo empregado, em sua origem, para referir-se a poetas de épocas posteriores àquelas consideradas clássicas em cada literatura, ou, ainda, a poetas de obra bastante restrita e que não desenvolveram todos os gêneros - especialmente aqueles gêneros considerados maiores, como é o caso da epopeia. Apesar de não ser exatamente essa a conotaçáo original, a denominaçáo de poeta menor, com o tempo, passou a ser tomada nas literaturas ocidentais também de modo pejorativo, com o propósito de designar náo apenas poetas de obra pouco extensa, ou exclusivamente lírica, mas também de obra esteticamente inferior - bem diferente da conotação que darão ao termo, mais tarde, Gilles Deleuze e Félix Guattari, sobretudo a partir da obra Kafka, Pour une littérature mineure, [Kafka, Por uma literatura menor], editada em 1975.

É a partir de tal duplicidade de significados que a afirmação de Bandeira, 
no poema Testamento ${ }^{3}$, de que seria ele um poeta menor, escandalizou inúmeros leitores e mesmo alguns críticos da época, que a consideraram severa demais, por terem se apegado apenas ao pior sentido possível do termo. Talvez justamente pela consciência do possível mal-entendido que sua afirmaçáo pudesse gerar é que Bandeira, cerca de uma década depois de escrito o poema Testamento, volte a essa questão em sua autobiografia quase que nos mesmos termos antes empregados em sua poesia. Contudo, seria enganoso pensar que a atitude do poeta é a de ir diretamente ao cerne da questão, simplesmente confirmando o que julgava mais adequado; a chave da compreensão da estratégia de Bandeira não está em flagrá-lo ao negar ou confirmar um conceito, mas sim em perceber como o autor gradualmente delineia a forma exata como pretende que tal conceito seja compreendido. Num primeiro plano, mais restrito, o poeta vai moldar sua própria imagem de poeta menor num diálogo constante com a história de sua obra e de sua formação humana e intelectual. Assim, ao enumerar seus poemas engajados socialmente, mais próximos, portanto, de uma poesia dos grandes temas, Bandeira comenta:

Em Chanson des Petits Esclaves e Trucidaram o Rio aparece pela primeira vez em minha poesia a emoção social. Ela reaparecerá mais tarde em $O$ Martelo e Testamento (Lira dos Cinqüent'Anos), em No Vosso e em meu Coração (Belo Belo), e na Lira do Brigadeiro (Mafuá do Malungo). Não se deve julgar por essas poucas e breves notas a minha carga emocional dessa espécie: intenso é o meu desejo de participação, mas sei, de ciência certa, que sou um poeta menor. Em tais altas paragens só respira à vontade entre nós, atualmente, o poeta que escreveu o Sentimento do Mundo e a Rosa do Povo. (BANDEIRA, 1958. p. 84, grifo meu)

\section{Carlos Drummond de Andrade, o poeta do Sentimento do Mundo} e da Rosa do Povo, é tomado como exemplo do poeta maior ideal, hábil no manejo dos grandes temas. Já Bandeira, cujas incursóes no terreno dos grandes assuntos humanos seriam apenas tentativas motivadas pelo desejo de ele também pensar através de sua poesia os problemas da sociedade, ou seja, seria uma exceção, uma fuga momentânea da temática do cotidiano, essa sim constante. É importante perceber que a figura de Drummond não é colocada por Bandeira como totalmente oposta à sua própria, é antes um tipo de poeta diferente, de temática diversa da sua e, ainda que haja uma pequena indicação de que a poesia dos grandes temas é que estaria nas

3 "Criou-me, desde eu menino. / Para arquiteto meu pai. / Foi-se-me um dia a saúde... / Fiz-me arquiteto? Não pude! / Sou poeta menor, perdoai!” (BANDEIRA, 2004, p. 181-182). 
"altas paragens", sendo portanto mais elevada. O próprio Bandeira vai se esforçar por mostrar o quanto a poesia considerada menor é, segundo ele acredita, resultado de um longo processo de evolução técnica, de trabalho intelectual árduo. Desse modo, o poeta aponta em sua autobiografia para uma dimensão mais ampla do conceito de poesia/poeta menor, e tal status vai equivaler ao do poeta que, além de dedicar-se a temas do cotidiano, não tem um percurso tão fácil quanto o do poeta maior, que acessaria facilmente o mundo das grandes abstraçôes, ou, nas palavras do próprio Bandeira:

Tomei consciência de que era um poeta menor; que me estaria para sempre fechado o mundo das grandes abstraçóes generosas; que não havia em mim aquela espécie de cadinho onde, pelo calor do sentimento, as emoçôes morais se transmudam em emoçóes estéticas: o metal precioso eu teria que sacá-lo a duras penas, ou melhor, a duras esperas, do pobre minério das minhas pequenas dores e ainda menores alegrias. (BANDEIRA, 1958. p. 22 , grifos meus)

Se, por um lado, lhe estáo fechadas as portas dos grandes temas, por outro, o poeta sugere - e eis aí o ponto de virada definitiva, no sentido de seu próprio engrandecimento como intelectual - que sua poesia, o seu metal precioso, seria fruto de duras esperas, de árduo trabalho artístico. $\mathrm{O}$ poeta menor transforma-se, definitivamente, naquele que, de longe, é quem realiza o maior trabalho, a mais profunda reflexão e, por consequência, a poesia mais adequadamente amadurecida. E, se se considera o Itinerário de Pasárgada como um todo, é possível perceber que essa autobiografia intelectual é, acima de tudo, a defesa e a afirmação de uma técnica construída ao longo de muitos anos.

Quando Bandeira diz, por exemplo, que:

O meu arrependimento [de ter começado estas memórias] vem do nenhum prazer que encontro nestas evocaçóes, da mediocridade que elas respiram, e ainda das dificuldades em que me vejo ao tentar refazer o meu itinerário no período que vai do ano de 1904, em que adoeci, ao de 1917, quando publiquei o meu primeiro livro de versos - A Cinza das Horas. Foi nesses treze anos que tomei consciência de minhas limitaçóes, nesses treze anos que formei a minha técnica. (BANDEIRA, 1958. p. 21)

Não só está chamando a atenção para o impacto negativo da doença em sua vida, mas também assinalando que a poesia que resultou dessa vivência tem, ao menos, treze anos de estudo acurado, de apuro técnico. 
O direcionamento proposto por Bandeira parece ter surtido um amplo efeito na crítica produzida sobre sua obra nos anos subsequentes à publicação do Itinerário de Pasárgada. Mesmo no Humildade, Paixão e Morte, de Davi Arrigucci Jr. (2003), publicado somente em 1990 e tido por muitos como a obra crítica definitiva sobre Bandeira, pode-se ver os efeitos da recepçáo da obra tal como preparada por Bandeira. O livro, que conta com um capítulo inteiro sobre o Itinerário de Pasárgada, toma por absolutamente legítimo e descompromissado o testemunho autobiográfico de Bandeira, sem questionar em momento algum a possibilidade de ser ele também um discurso literariamente intencionado, que pode, além disso, carregar em si o desejo de moldar e, até mesmo, impor toda a recepção de uma obra literária. $\mathrm{O}$ texto do Itinerário é utilizado, de modo um tanto inocente, como meramente referencial e informativo, e, portanto, visto como uma fonte privilegiada e ideal para legitimar qualquer hipótese ou interpretação que se possa formular sobre a poesia de Bandeira, pois é como se o próprio poeta corroborasse o que diz o crítico ou, nas palavras de Davi Arrigucci Jr.: "O caminho foi indicado pelo próprio poeta. Convém tomar-lhe a mão e seguir-lhe os movimentos da consciência artística" (ARRIGUCCI JR., 2003, p. 124). Desse modo, as declaraçôes de Bandeira no sentido de aparentemente diminuir sua própria importância, como é o caso de o autor se dizer um poeta menor, são tomadas por sintomáticas de um poeta "cuja humildade deve ser considerada um modo de ser e um traço de estilo" (ARRIGUCCI JR., 2003, p. 125) e que "humildemente se reconhece poeta menor" (ARRIGUCCI JR., 2003, p. 125), humildade que passa a figurar como fio condutor dessa e de tantas outras leituras que se fizeram de sua poesia. De fato, a poesia de Manuel Bandeira está erigida sobre uma temática do cotidiano, e o intuito neste momento é mostrar como foi fundamental, para a aceitaçáo dessa poesia e para que figurasse ao lado de outros autores de temas maiores, a definição exata do que seria essa poesia menor e, ainda, a valoração de algumas linhas temáticas dentro das quais seus poemas passariam a ser lidos.

É interessante pensar, após ter examinado o uso que Manuel Bandeira fez de sua autobiografia como um exercício de preparaçáo da crítica, que, por acaso ou náo, parece que o poeta se acostumou e se rendeu de uma vez por todas à prática que táo efusivamente havia negado. Pois percebe-se que sua prosa sofreu um verdadeiro "surto autobiográfico" no período posterior à edição do Itinerário de Pasárgada. Ao observar-se a temática da obra em prosa de Bandeira antes do Itinerário, constata-se que suas crônicas tratam, antes de mais nada, de arte - seja ela literatura, pintura, música ou 
arquitetura -, poucos são os momentos em que é a experiência pessoal de Bandeira que conduz a escrita. Contudo, de 1954 até o fim de sua vida, em 1968, a situação se inverte e o poeta vai adotando um tom cada vez mais pessoal em seus escritos, falando muito de si, tomando sua própria percepçáo como ponto de partida para suas reflexóes sobre arte, comentando sua obra poética e mesmo acrescentando episódios autobiográficos que bem poderiam figurar ao lado daqueles que estão relatados em suas memórias. Prova dessa tendência em direção à escrita autobiográfica é que foi possível a Carlos Drummond de Andrade, quando organizou o volume de crônicas de Bandeira intitulado Andorinha, Andorinha, criar toda uma seção, a que chamou de Primeira pessoa do singular, reunindo cerca de 30 crônicas. As crônicas desta parte do volume, claramente autobiográficas, são datadas e, como já era de se prever, as datas são quase todas do fim dos anos de 1950 e início dos anos de 1960.

Passando a Oswald de Andrade, é possível dizer que sua autobiografia parece, a todo momento, querer afirmar sua figura transgressora, vanguardista e libertária, tanto na obra quanto na vida. Já no início de seu texto, o autor representa-se como o homem que esteve sempre à frente, lutando - ele mesmo mobiliza expressóes do campo lexical da guerra - por uma causa: "Fito nas paredes do living espaçoso as minhas altivas bandeiras. São os quadros, as obras-primas da pintura moderna de que breve vou me desfazer. São os estandartes levantados na guerra que foi a minha vida." (ANDRADE, 2002, p. 35-36). É possível acompanhar, seguindo as páginas de Um homem sem profissáo, todo o percurso de descoberta de Oswald e também de distanciaçáo dos padróes comportamentais do meio em que vivia, é possível ver o "filho bem-educado de D. Inês, o rapaz que tinha família em Caxambu, o matriculado na Lógica do padre Sentroul e no Direito Romano do professor Porchat" (ANDRADE, 2002, p. 150) lançando-se à vida, descobrindo o amor, o sexo, as artes, etc. $\mathrm{O}$ autor evoca seu contexto de origem recorrentemente para se opor a ele, criando assim o personagem que desde sempre foi um contestador.

No trecho de $\mathbf{O}$ saláo e a selva, que Oswald deixou escrito antes de falecer, incorporado à edição mais recente de Um homem sem profissáo, encontra-se um trecho exemplar de sua constante negaçáo das instituiçôes tradicionais. $\mathrm{O}$ autor, ao comentar a insistência da mãe para que ele tivesse um diploma universitário, diz: "Pobre mãe que ignorava a vocaçáo de irregularidade e de sublevação de seu filho, inconformado sempre, sempre inimigo dos diplomas e das posiçôes" (ANDRADE, 2002, p. 209). E prossegue destacando três figuras ilustres da Faculdade do Largo de São 
Francisco: Castro Alves, Álvares de Azevedo e Fagundes Varela. Oswald não consegue imaginar esses três intelectuais no meio em que viviam e questiona-se: "Como teriam vivido eles em meio de estudantes de Direito numa Faculdade colonial portuguesa, num planalto agreste, feudalizado por cônegos, fazendeiros escravocratas e os procuradores de seus interesses que eram os advogados?” (ANDRADE, 2002, p. 210). Para o que conclui:

\begin{abstract}
Calculo o drama obscuro dessas almas penadas no Inferno da mesquinha vida universitária paulistana. Como se sabe, ao contrário do que aconteceu na América Espanhola, nunca se tratou de trazer para o Brasil uma universidade. Fundaram-se simplesmente os cursos jurídicos. Aqui e em Recife isso bastava porque fornecia o bacharel, a alma e o exato dos interesses da classe senhoril (ANDRADE, 2002, p. 210).
\end{abstract}

Oswald critica o conservadorismo da instituição acadêmica brasileira, dando destaque à sua inadequaçáo a esse meio e, ao mesmo tempo em que se questiona sobre a situaçáo dos três intelectuais libertários imersos num meio conservador, acena para uma identificação com eles. Assim, mesmo ao se filiar a figuras de uma tradição literária, Oswald opta por se posicionar ao lado justamente do Romantismo, a primeira corrente que se colocou sob o signo da contestação e da liberdade, negando padróes e valores tradicionais. Do mesmo modo que Castro Alves, Álvares de Azevedo e Fagundes Varela, Oswald vai representar - ou melhor, se representar como - uma exceçáo no meio retrógrado do Largo de São Francisco, uma exceção que acabaria por se constituir como uma promessa de renovaçáo, de superação das amarras coloniais e antiquadas da sociedade brasileira.

A transgressão e o vanguardismo não vão restringir-se, na automodelagem de Oswald, somente ao plano intelectual, vão perpassar toda a formação de sua personalidade. Desde o início da narrativa oswaldiana, entram em cena detalhes extremamente íntimos de sua vida, pormenores um tanto inesperados numa autobiografia escrita no momento em que Um homem sem profissáo foi criada. Trechos que, como o que cito adiante, poderiam chegar a chocar um leitor mais conservador, não porque algo assim não existisse, mas porque a praxe era que tais detalhes não fossem nunca mencionados:

[...] cedo mergulhava eu nesse maravilhoso universo da bronha onde permaneci virgem até a maioridade. Vivia arrebanhando pretextos e motivos para a elaboração noturna de meu sonho sexual. [...] As mocinhas de maiô entraram em meus olhos e aí permaneceram. Nas noites de camisoláo elas 
foram meu pasto e minha festa. Nesse tempo, aqui, ninguém usava pijama e minha mãe, à entrada de cada inverno, me presenteava com um comprido e folgado camisoláo da boa lã daquele tempo. [...] Entâo se descerravam os umbrais de meu mundo secreto. Geralmente uma daquelas moças tinha partido o calção na aula de ginástica e subia os degraus da galeria para que eu o ajustasse. $\mathrm{O}$ camisoláo era o pano do circo que o mastro central enfunava. E as "pastorinhas de meu sexo" do poeta Luís Coelho, pelos olhos encantados da invençấo, vinham até mim, para consertar, róseas, frescas, faiscantes, os seus maiôs rasgados. (ANDRADE, 2002, p. 37-38)

Mesmo as metáforas que aparecem no texto oswaldiano - como a que se vê em "O camisoláo era o pano do circo que o mastro central enfunava" -, que a princípio teriam a função de minimizar o impacto do que se diz, não têm valor eufemístico, mas, ao contrário, tornam a cena da fantasia sexual e da masturbação ainda mais viva e talvez mais chocante para certos leitores da época que assim são, de certo modo, "obrigados" a entrarem na fantasia e no jogo do autor. Tais episódios ganham ainda mais interesse - e tornam-se igualmente mais surpreendentes - quando não se referem mais ao menino, mas sim ao homem já feito, como nos episódios em que Oswald evoca sua descoberta da liberdade sexual europeia ou ainda do affaire que teria tido com a bailarina americana Isadora Duncan. Creio que, nesse contexto, referências tão absolutamente desveladas à sexualidade, o tratamento aberto e o emprego recorrente do tema, significaria reforçar o posicionamento de Oswald contra uma sociedade que se fundava sobre convençôes estanques. Além disso, a importância dada em sua autobiografia para a formaçấo intelectual europeia poderia significar também, para Oswald, uma afirmaçáo de seus ideais frente a outras correntes no interior do Modernismo brasileiro, como, por exemplo, a corrente do Movimento Verde-amarelo, que tinha entre suas principais divisas a recusa do que chamavam de "perigo estrangeiro".

Há que se destacar também a forte presença da noção de matriarcado na autobiografia de Oswald - presença marcada já no próprio título do volume através da metáfora do "sob as ordens de mamáe" -, noção que foi tão importante na formulação do conceito de antropofagia. No Manifesto Antropófago, publicado na primeira ediçáo da Revista de Antropofagia, em maio de 1928, Oswald escreve que somente a antropofagia - que seria a expressão de uma forma matriarcal de conceber o mundo, oriunda do direito materno, da coletivização do solo e da sociedade sem estado teria a capacidade de nos unir em todos os diversos aspectos da realidade, reabilitando o conceito primitivo de vida como devoração, em oposiçáo à 
cultura messiânica característica da tradição patriarcal e escravocrata. Para o poeta, a reabilitação do primitivo e o retorno ao princípio inclusivo e feminino do matriarcado de Pindorama permitiriam ultrapassar a visão que opóe e traça um percurso evolutivo do bárbaro (homem natural) ao civilizado, o que seria possível com a emergência de um novo termo, o "bárbaro tecnizado", resultado inovador da transubstanciaçáo do segundo no primeiro pelo rito antropofágico, numa operação criativa que alterna e ignora o impasse do atraso. A figura da mãe ocupa um espaço de destaque em Um homem sem profissáo e sua perda, ocorrida no período coberto pelo livro, consistirá num importante ponto de transiçáo na narrativa:

\footnotetext{
O meu dissídio com Deus produziu-se no dia 13 de Setembro de 1912. Foi aí que, tendo regressado da Europa e descido no Rio, vim pelo trem noturno e desembarquei na Estação da Luz por uma manhã molhada de primavera precoce. A maneira por que um grupo de amigos e familiares me rodeou e abraçou me fez perceber que alguma coisa muito grave se tinha passado. De fato, minha mãe não existia mais. Tinha falecido apenas alguns dias antes. Seis dias. Sem poder ao menos esperar o meu regresso (ANDRADE, 2002, p. 118).
}

Como é possível notar, à morte da mãe corresponderá também uma morte simbólica de Deus e, a partir dela, virá uma definitiva distanciação dos padróes e instituiçóes convencionais. Seria após a visita ao cemitério em que a mãe fora recentemente sepultada que Oswald declararia que sairia "Dali para a casa e para a vida." (ANDRADE, 2002, p. 120). E a vida do poeta, ao menos em sua narrativa, se torna ainda mais intensa após a morte da mãe, atingindo um ritmo cada vez mais vigoroso, englobando vivências mais ousadas, sejam elas sexuais e afetivas ou sejam intelectuais. Todos esses elementos entrecruzam-se, mesclam-se e produzem um todo coeso, nas palavras de Anderson Pires da Silva (2009, p. 60), em Mário e Oswald: uma história privada do modernismo: "A liberdade sexual constituía um dos traços "modernos" que o matriarcado prefigurava, e era o que Oswald fora buscar na Europa. O mal da colonização resultava da repressão jesuíta ao corpo - que pena que o português vestiu o índio, fosse o contrário...”.

Os traços que avultam nas muitas leituras que se tem feito da obra de Oswald de Andrade são, sem dúvida, sua posição sempre radical, não importa qual fosse o assunto, seu caráter vanguardista e transgressor. Proponho que essas leituras críticas não são resultado exclusivo daquilo que as obras e a ação de Oswald realmente foram e são, mas que também dessas interpretaçôes participam as representaçóes que o próprio autor somou à fortuna crítica de 
sua obra e que, muito provavelmente, tiveram papel de relevo na recepção de seus escritos. Veja-se, por exemplo, o texto que Haroldo de Campos escreveu, em 1966, por ocasião da publicação das Poesias Reunidas, de Oswald de Andrade (1974), uma ediçáo importantíssima, que além de ter sido a primeira ediçáo comercial da poesia reunida de Oswald, ainda teve papel de relevo na constituição do paideuma concretista. Campos antepóe aos textos por ele compilados e organizados um longo artigo, intitulado Uma poética da radicalidade, em que há um esmerado estudo que, ao lado da reedição dos poemas, vai agir no sentido de promover uma releitura e uma revalorização crítica da poesia de Oswald, que permanecia um tanto quanto "esquecida" naquele momento. Bastam as primeiras palavras do texto de Haroldo de Campos - "Se quisermos caracterizar de um modo significativo a poesia de Oswald de Andrade no panorama de nosso Modernismo, dizemos que esta poesia responde a uma poética da radicalidade. É uma poesia radical" (CAMPOS, 1974, p. 09, grifo meu) - para que se perceba como o traço mais marcante destacado pelo autor é justamente a radicalidade de sua poesia. Mais à frente, Haroldo de Campos ainda soma à percepção da radicalidade, o desejo de dessacralização da literatura, expresso no Manifesto Poesia Pau-Brasil, bem como o desejo posterior de construçáo, "que rearticula os materiais preliminarmente desierarquizados" (CAMPOS, 1974, p. 28).

O estudo dessas duas autobiografias permite observar e compreender algumas das práticas de legitimaçáo de figuras da literatura nacional, evidenciando alguns dos procedimentos pelos quais os escritores brasileiros, a partir de meados do século XX, buscaram cuidar e definir seus perfis públicos. A elaboração de uma imagem desejada de autor e o interesse do próprio autor em definir algumas das linhas mestras da leitura futura de sua produção acabam por tornar-se fatores decisivos para que, a partir dos anos de 1950, momento em que Bandeira e Oswald o fazem, narrar a própria vida através de autobiografias, memórias, diários e cartas tenha adquirido especial interesse, em particular para aqueles escritores ligados ao Modernismo de 1922. Assim, pude ler o livro de Bandeira buscando entender sua pretensa má-vontade em criar uma narrativa autobiográfica como uma oportunidade de legitimar seu testemunho e articulá-lo de acordo com seus interesses na representação de si e de sua obra, algo que é recorrente nas autobiografias em geral, mas que vejo como um traço dominante nas autobiografias de autores modernistas brasileiros. Foi bastante significativo, ainda, constatar que a crítica literária da obra de Bandeira posterior ao Itinerário seguiu, um tanto inocentemente, a imagem por ele representada na autobiografia, 
reproduzindo traços de uma concepção das escritas de si como um espaço de acesso privilegiado à verdade sobre a obra literária. Oswald de Andrade, por sua vez, articula sua autobiografia no sentido de que ela seja um ato crítico continuador da proposta estética e política de sua obra. Além disso, o autor cria um complexo jogo de ligaçóes entre Um homem sem profissáo e suas outras obras, colocando em questão as fronteiras entre autobiografia e ficção, num processo também identificável, a cada dia com mais intensidade, na produção autobiográfica brasileira.

\section{Referências}

ANDRADE, Oswald. Um homem sem profissão; Memórias e Confissóes; Sob as ordens de mamãe. 2. ed. São Paulo: Globo, 2002.

ARRIGUCCI JR., Davi. Humildade, paixáo e morte. A poesia de Manuel Bandeira. 2. ed. São Paulo: Cia. das Letras, 2003.

ARTIÈRES, Philippe. Arquivar a própria vida. Estudos Históricos, Rio de Janeiro, v. 11, n. 21, 1998, p. 14.

BANDEIRA, Manuel. Itinerário de Pasárgada. In: Poesia e Prosa. Vol. 2. Rio de Janeiro: Aguilar, 1958.

CAMPOS, Haroldo de. Uma poética da radicalidade. In: ANDRADE, Oswald. Poesias Reunidas. Rio de Janeiro, Civilização Brasileira, 1974.

MATHIEU-CASTELLANI, Gisèle. La Scène judiciaire de l'autobiographie. Paris: PUF, 1996.

MIRANDA, Wander Melo. Corpos Escritos: Graciliano Ramos e Silviano Santiago. São Paulo: EDUSP; Belo Horizonte: Editora UFMG, 1992.

SABINO, Fernando. O Tabuleiro de Damas. In: Obra Reunida. Vol. 03. Rio de Janeiro: Nova Aguilar, 1996. 
SILVA, Anderson Pires da. Mário e Oswald: uma história privada do Modernismo. Rio de Janeiro: 7Letras, 2009.

SOUZA, Eneida Maria de. Crítica Cult. Belo Horizonte: Editora UFMG, 2002.

Recebido: 29/03/2018

Aceito: $28 / 07 / 2018$

DOI - http://dx.doi.org/10.5902/2179219431918 